\title{
Methodology for assessing the cross-impact of state programs' implementation
}

\author{
Tatyana S. Khudyakova, Svetlana V. Doroshenko
}

\begin{abstract}
The paper examines the cross-impact of state programs' implementation. The research methodology rests upon the theory of public management efficiency, the concept of New Public Management and the system-based approach to its analysis. In the course of the study, the authors apply the regulatory, comparative and context methods and the verbal modelling. The researchers review a number of scientific works and reference documents, as well as perform a content analysis of the regulatory framework in the subject area under consideration. The article substantiates the relevance and the need for investigating cross-program effects and identifies the prerequisites for the improvement of state programs' effectiveness evaluation. The study clarifies the meaning of the term "crossprogram effect" and discusses how it differs from a multiplier effect. The research presents a classification of cross-program effects and develops the methodological guidelines and the conceptual diagram for assessing the cross-impact when implementing state programs in a constituent territory of the federation. The authors propose the indices such as the cross-impact of a state program and the cross-effectiveness of a state program and outline the difficulties and limitations of the given approach to the assessment of cross-program effects. The results the evaluation are expected to optimize and improve the mechanisms of the program budgeting and strategic planning.
\end{abstract}

Keyw ords: cross-program effect; state program; assessment of cross-program effects; constituent territory of the federation.

JEL Classification: H83, D78, G38

Funding: The paper is supported by the fundamental research project of the Ural Branch of the Russian Academy of Sciences No. 18-6-7-18 "Scientific and technological development of regions on the principles of the green economy".

Paper submitted: December 16, 2018

For citation: Khudyakova T.S., Doroshenko S.V. Methodology for assessing the cross-impact of state programs'implementation. Upravlenets - The Manager, 2019, vol. 10, no. 2, pp. 41-48. DOI: 10.29141/2218-5003-2019-10-2-5.

\section{INTRODUCTION}

State programs implemented at federal and regional levels and covering various avenues for the socio-economic development of the Russian Federation are among relatively novel tools of public economic management designed to boost the efficiency of budget spending. State programs' effectiveness assessment is a principal element in enhancing the performance of the public sector that continues to be debated in academia. The methods widely practiced to evaluate the effectiveness of state programs prove the necessity to modify the existing approach due to a number of significant drawbacks that encompass the following: a remarkable preponderance of quantitative indicators over qualitative ones and in some cases the use of exclusively quantitative indicators; assessing the effectiveness of government programs predominantly by analysing their performance indicators; insufficient amount or absence of performance indicators; the prevalence of a generalized and formal approach to assessing the effectiveness of state programs in the region; contradicting interpretations of the indicators' values; the application of various rating scales to assign the resulting values, such as "high effectiveness", "medium effectiveness" and "low effectiveness" and unavailability of effectiveness gradations in some regions. For example, to evaluate the effectiveness of the state programs aimed at supporting small and medium-sized businesses, $70 \%$ of the Russian regions practice the same technique used for all other government initiatives implemented within the region. Despite the fact that these programs are multicomponent and multifaceted, the method often exercises a simplified and formal approach [Bykova, 2014, p. 109; Konovalova, Akimova, 2016, p. 20; Neu- pokoev, 2014, p. 263]. It is also revealed that $70 \%$ of the constituent territories of the Russian Federation use only quantitative indicators to assess the effectiveness of state programs for the development of small and medium-sized businesses (SMEs). The most commonly used of them are the degree to which the planned values of the indicators are fulfilled ( $99 \%$ of the regions), the funding volume ( $91 \%$ of the regions) and the accomplishment of the program measures $(67 \%$ of the regions). The first indicator characterizing the fulfillment of the targeted values can be interpreted differently: if the planned values are exceeded, it can be viewed as both a positive (for instance, in Kurgan oblast) and negative (Sverdlovsk oblast) trend. When evaluating the effectiveness of state-run SME development programs, only $27 \%$ of the Russian regions apply the effectiveness indicator in parallel with some performance indicators, whereas approximately half of the constituent territories (46\%) use solely the aforementioned performance indices.

Moreover, the effectiveness is currently assessed within an individually selected state program with no cross-program influences taken into account, whereas the effects obtained may represent an overall result of the interaction between several government programs. In other words, we can see the so-called cross-program effect emerging here that is poorly studied and evaluated as of yet. We suppose that, when assessing the effectiveness of state programs, it is reasonable to bear in mind cross-program impacts that arise if the same constituent territory of the federation implements several government programs at a time. Such an assessment is especially mainstreamed by the Methodological Guide- 
lines for the Development and Implementation of the State Programs of the Russian Federation'. The document stipulates the necessity to identify the central measures of a state program that are able to affect the fulfilment of the goals and tasks specified in other state programs performed within the same region, and vice versa [Khudyakova, 2018, p. 227]. In addition, the consolidated annual report of the Ministry of Economic Development of the Russian Federation, devoted to the implementation and evaluation of the effectiveness of state programs of the Russian Federation following the results of 2017, emphasizes the need and intention of the Ministry to tackle the issue of forming a system of state programs' cross-impact assessment.

Thus, at the moment there is a need to evaluate, firstly, the entire portfolio of state programs at federal or regional levels; secondly, the cross-impact of state programs; and thirdly, the influence of the whole set of state programs on not only the achievement of a goal stated in each program, but also the development of individual processes, phenomena and fields of activity, for example, the transition to a digital economy, increasing entrepreneurial activity, the evolution of civil society, etc.

Given the abovementioned shortcomings and trends in the practice of state programs' effectiveness evaluation, as well as the requirements of the current regulatory documents, the present research is aimed at developing methodological guidelines for assessing the cross-impact of government programs when implementing them in a federation constituent territory.

The tasks of the study are: 1) to analyze the approaches to the assessment of state programs' implementation effects employed in the scientific literature; 2 ) to clarify the meaning of the term "a cross-program effect"; 3 ) to systematize the types of cross-program effects; 4) to develop the methodological principles and the conceptual diagram for the assessment of cross-program effects.

During the study, the authors apply the regulatory, comparative and context methods and the verbal modelling. The regulatory method was adopted to scrutinize the regulatory documents containing the details of government programs, methods for their development and evaluation with a view to examining the existing practice of state programs' assessment. With the help of the comparative method, we look at the goals, tasks and activities enshrined in state programs in order to identify those government programs affecting the same field of the socio-economic development. The context method is utilized to investigate the texts of programs' documentation for the purpose of revealing logical links between government programs. The verbal modelling is applied to design a conceptual diagram for assessing cross-program effects with the subsequent development of the assessment technique.

\footnotetext{
${ }^{1}$ The Methodological Guidelines for the Development and Implementation of the State Programs of the Russian Federation: approved by the order of the Ministry of Economic Development of the Russian Federation of September 16, 2016 No. 582.
}

The information base of the analysis conducted includes regulatory documents approving state programs at federal and regional levels and the methods for their assessment published on the official website of the Russian Federation's government programs and the websites of the governments and departments of economic development of the Russian regions.

Theoretically, the proposed methodological guidelines for assessing the cross-impact of state programs rely on the principles of the New Public Management concept that superseded the bureaucratic theory of Max Weber underlying the administrative and budget reform in the Russian Federation in 1990-2000:

- the unity of mechanisms ensuring public administration;

- avoiding the cost principle of public administration and the transition to the principle of performance management;

- optimization of the state apparatus, including through reducing the costs incurred in public administration and cutting the functions of government authorities (outsourcing);

- search and formation of the model of the effective state;

- an emphasis on changes in the system, rather than its sustainability;

- the prevalence of purposes and tasks over rules and directives;

- orientation towards implementation of objectives, tasks and functions of public management from the perspective of a value-centric approach.

\section{THE CROSS-IMPACT OF GOVERNMENT PROGRAMS'IMPLEMENTATION}

A wide array of Russian and foreign studies substantiates the need for unveiling diverse cross-program effects. For example, Goloushkin [2012, p. 131] notes that using only quantitative data for program evaluation does not allow one to foresee the side effects of the implemented program, which might be more important and long-term than the selected target values. Shash $[2015$, p. 12] emphasizes the importance of taking into account the indirect effects of the implementation of government programs that relate to other fields of the socio-economic development. These authors highlight the formation of the so-called multiplier effect, which denotes an integrated effect exerted by an object (in this case, a program) on the economy. The term "multiplier" was first coined by the English economist R.F. Kahn in 1931 to demonstrate that government spending on the development of one economic sector stimulates improvements not only in this sector, but also in the economy as a whole. The necessity to explore multiplier effects is due to the large amount of cause-and-effect relationships arising in economy, which means that changes in some parameters of the economic system inevitably result in changes in other economic indicators. Recording and measuring these mutual influences one allow to improve public economic management.

The modern Russian and foreign practice exhibits various approaches to assessing the effectiveness of state programs'implementation [Patrakhina, 2015, p. 66]. A number of 
authors emphasize that the scientific grounding of the methods for assessing the effectiveness of the implementation of state programs is insufficient [Levitskaya, Savelyev, 2016, p. 74]. Rukina and Samodurova [2017, p. 112] find that an analysis of the efficiency of budget spending should include the assessment of all the resources, such as financial, administrative, etc. We suppose that this approach is applicable, if the evaluation of government programs' effectiveness is based on the cumulative interaction of several state programs' resources. Breusova $[2015$, p. 133] points to the necessity for adjusting the content of state programs so that to reduce their cost but keep the results and the quality at the same level. Shmigol [2017, p. 124] stresses the usefulness of comparing government programs with each other and holding a periodic reassessment of functions and tasks assigned to federal executive bodies in order to identify obsolete, duplicate and ineffective programs. Blinova [2012, p. 91] underlines the importance to analyze the impact of state programs on the socio-economic development of the region.

It is worth noting that the current regulatory documents focus on the same. For example, The Guidelines for the Development, Implementation and Evaluation of the Effectiveness of Government Programs in the Russian Federation ${ }^{1}$ stipulate the necessity to evaluate the contribution of a state program to the entire socio-economic development of the Russian Federation and to establish the impact of the state program's projected results on various spheres of the Russian economy. In addition, it is specified that such assessments may embrace both direct (immediate) effects from the state program's implementation and indirect (external) effects emerging in the related sectors of the Russian economy. Another methodological document that deals with the assessment of effects in the related areas is the Methodological Recommendations for Evaluating the Efficiency of Investment Projects approved by the Ministry of Economic Development of the Russian Federation together with the Ministry of Finance and the State Committee of the Russian Federation for Construction, Architectural and Housing Policy. This document makes it obligatory to take into account the socio-economic consequences for society at large, including both immediate results and external effects in the related economic sectors, as well as environmental, social and other effects. The issues of the cross-impact and interdependence of various elements within a single socio-economic system are also addressed by a number of foreign authors [Ka Wai Lai, 2015, p. 64; Menck, Weidig, Aurich, 2014, p. 496; Weimer-Jehle, 2006, p. 339].

Appreciating the significance of the scientific results obtained, we believe it important to note that most of them cover multiplier effects, whereas the issues of the cross-impact remain poorly examined.

In our opinion, a cross-program effect should be distinguished from a multiplier effect. The latter demonstrates an integrated influence of a particular project or program on the

${ }^{1}$ The Guidelines for the Development, Implementation and Evaluation of the Effectiveness of Government Programs in the Russian Federation: approved by the decree of the RF Government of August 2, 2010 No. 588. economy, while a cross-program effect implies the impact of different government programs on each other (through goals, tasks, indicators, measures) or the development of an individual sphere (e.g. small and medium-sized enterprises), or the fulfilment of the contextual development goals (e.g. the digital economy). Thus, a cross-program effect is an outcome of the interaction between two or more programs that is manifested in the impact on the fulfillment of goals, tasks, program indicators and/or the conditions for programs' implementation. It is noteworthy that a cross-program effect can contribute or hinder the achievement of program targets, improve or worsen program results, create new ones, as well as exert an influence on the conditions for program implementation.

Thus, a cross-program effect exists in a situation, where there are links between the programs involved, in particular, if the activities of one program affect the outcome of the other one. A cross-program effect can be the result of both the cross-impact of government programs and the influence of government programs on other processes, phenomena, activity areas (as mentioned above, small and medium-sized businesses), whose development is strictly controlled by public authorities. Another situation is where a cross-program effect derives from the cross-impact of the implementation of a set of state programs on phenomena and processes predetermined by development goals, including those left beyond the scope of these programs, e.g. the achievement and implementation of goals and tasks of the green economy development in the Russian regions [Doroshenko, Trushkova, Khudyakova, 2018, p. 424].

In general, when assessing cross-impacts, it is important to consider that performance of the evaluation and correctness of the results depend on the exact choice of the list of government programs that are interconnected or directly or indirectly affect the scope, phenomenon or process selected for evaluation.

\section{CLASSIFICATION OF CROSS-PROGRAM EFFECTS}

Proposing a classification of cross-program effects contributes to a more in-depth comprehension of their essence. Moreover, categorizing cross-programs effects into various groups is the stage necessary for the subsequent development of the method for cross-program effects' integrated assessment. We define a number of criteria for classifying cross-program effects. The choice of these criteria is driven by not only the role or mechanism of the effects' occurrence, but also the form of the connections, the intensity of the effects, as well as several other significant aspects. We establish the following criteria for the classification of cross-program effects: the sphere of the effect occurrence; the impact on the results of state programs; the mechanism of occurrence; the form of relationships that created the effect; the severity of the effect; the nature of the results; the attitude to the system; the scale of manifestation and the scope of application.

Considering that cross-program effects occur in the socioeconomic sphere, we distinguish between the following their types: budgetary, institutional, social, managerial, regulatory, 
organizational, informational, consulting, tax, innovative, environmental, demographic, macroeconomic, commercial, etc.

By their nature, the cross-impact of government programs can be of two types:

- positive cross-program effects that allow saving resources, reducing the time to obtain results, producing more satisfactory outcome delivering surprising results unforeseen by the program, improving the conditions for the program's implementation;

- negative cross-program effects are characterized by the rising resources consumption, the increasing time to get results, worsening results and conditions for the government program's implementation.

By the mechanism of occurrence, the cross-program effects can be:

- direct (having an immediate influence on the outcome of state programs);

- indirect (affecting the conditions and the resource base for the implementation of state programs).

By the form of relationships creating the effect (orientation), the cross-program effects can be divided into:

- unilateral (one state program exerts an influence on the results and conditions for another state program, while not experiencing any cross-impact);

- bilateral (there is a cross-impact between two government programs).

By the severity of the effect, we categorize cross-program effects into weak, medium and strong. By the nature of the results, they can be quantitative and qualitative. By the attitude to the system, internal and external. By the scale of manifestation, sectoral, municipal, regional, interregional, federal, international. By the scope of application, micro- and macroeconomic.

The authors concede that the proposed classification and criteria are incomplete and can be expanded and refined further, but within the framework of this study, the proposed classification of cross-program effects served as the basis for developing methodological guidelines for their evaluation.

\section{METHODOLOGICAL GUIDELINES}

\section{FOR ASSESSING CROSS-PROGRAM EFFECTS}

The authors have developed the following methodological guidelines for assessing cross-program effects.

1. The assessment of cross-program effects should take into account the interests of the main stakeholders, such as public authorities, local governments, population, business community and non-profit organizations. At that, balancing the interests of different parties can be simultaneous and carried out from the position of only one stakeholder, e.g. government authorities or the business community. Within the scope of the current research, cross-program effects are explored primarily from the standpoint of public authorities.

2. The object of the assessment of cross-program effects is a set of government programs. The assessment implies the analysis of a set of programs implemented in the constituent entity of the federation in order to check if there are links between them, for instance:
- One government program produces the results that are subsequently used as the basis for the implementation of another government program (e.g. the program "The Development of Science and Technology" provides all the input data required for the implementation of the program "The Development of the Manufacturing and Increasing Its Competitiveness");

- One government program creates the resources or the environment needed for the implementation of another government program (e.g. the program "The Development of the Transport System" provides the resources for the program "Economic Development and Innovation Economy");

- One government program regulates or creates restrictions for another government program (for example, the program "Environmental Protection" regulates the program "Development of Forestry");

- The implementation of several government programs (including "Environmental Protection", "Energy Efficiency and Energy Development", "Reproduction and the Use of Natural Resources") will allow achieving some of the contextual goals of the green economy.

Such an assessment suggests applying the pair-wise comparison, as well as the contextual and expert methods. Undoubtedly, with the growing number of government programs evaluated collectively, the assessment becomes more labour intensive, but this is offset by its increasing effectiveness and ultimately by a gain in the efficiency of using budget funds.

3. The assessment of cross-program effects is premised on the following methodological principles:

1) there are links between the government programs. To assess the cross-impact, there should be links between at least two government programs;

2) taking into account quantitative and qualitative assessment indicators. The intensity of cross-program effects is denoted through quantitative data, whereas the scale of their manifestation - through qualitative ones;

3) uniqueness of the results. Every cross-program effect revealed is valid only for the set of the state programs under consideration. If the set of the programs is changed, a new analysis needs to be performed;

4) practical implications of the findings. The results of the evaluation should improve strategic planning mechanisms and program budgeting;

5) in-depth coverage. To make sure that the assessment of cross-program effects is objective, it is necessary to analyze all the state programs that, while implemented, can exert a certain effect on the sphere or object under study.

4. The scope of cross-program effects assessment, on the one hand, can be limited to a specific research area (for example, small and medium-sized entrepreneurship) and a research object (a constituent territory of the federation). As for the constituent territory under review, the scope of the research is a particular government program. With such an assessment of cross-program effects, the goals and tasks of the key program should be compared pair-wisely with the activities of the other state programs implemented in the constituent territory of the 
federation, as well as it is necessary to compare pair-wisely the goals and activities of all state programs affecting the key state program.

On the other hand, the scope of cross-program effects assessment can be established contextually, e.g. the achievement by the region of the objectives of sustainable development, the digital economy, the implementation of the principles of green economy. With such as approach, the key program is also determined, which is later compared pair-wisely with the other government programs.

5. The links between the activities of one state program and purposes/tasks of another one serve as the source for generating cross-program effects. There are two ways for analyzing the cross-impact for every government program:

1) establishing the number of the state program's major activities affecting the implementation of other state programs;

2) establishing the number of state programs that are influenced by each major activity of the state program under discussion.

The presence of links between government programs is determined through content analysis of the existing program documents.

6. Revealing the strength of the links between state programs is founded on the hierarchy analysis method and expressed through the index of the cross-impact of a particular government program, which means a quantitative characteristic of the impact that the activities of one program exert on the purposes and tasks of another government program. The cross-impact index of the same state program can vary depending on the set of programs under consideration.

7. The indices of the state programs' cross-impact are applied to assess their cross-effectiveness. The cross-effective- ness of a state program is a quantitative characteristic of the severity of cross-impacts exerted by a particular state program on other government programs taken together.

8. To identify the state programs with the most dramatic influence, they are ranked according to the cross-effectiveness indicator. The greater its values, the larger the number of measures of a specific state program that positively affect the goals and tasks of other programs considered together.

9. The results of the evaluation of cross-program effects should help optimize and improve the mechanisms of program budgeting and strategic planning. The results should embrace recommendations on the necessity to induce changes in the lists of approved federal and (or) regional state programs; in the statement of purposes, tasks and the state programs' activities; in the mechanism and amount of funding for state programs; and in the list of state programs' executives and participants.

Based on the abovementioned methodological guidelines, the authors propose a conceptual diagram for assessing the cross-impact of the implementation of state programs in a constituent territory of the federation (see Figure).

The conceptual diagram presents the interrelation between the main elements of the assessment of cross-program effects in a constituent territory of the federation. The inputs of this activity are the program documents valid in the selected constituent territory of the federation, namely the goals, tasks and activities of each state programs implemented in the region. The projected outputs (results) of the assessment are, firstly, cross-program effects stemming from the integrated interaction of government programs, and, secondly, the data on cross-program effectiveness of each state program. The magnitude of the cross-program effectiveness depends on the

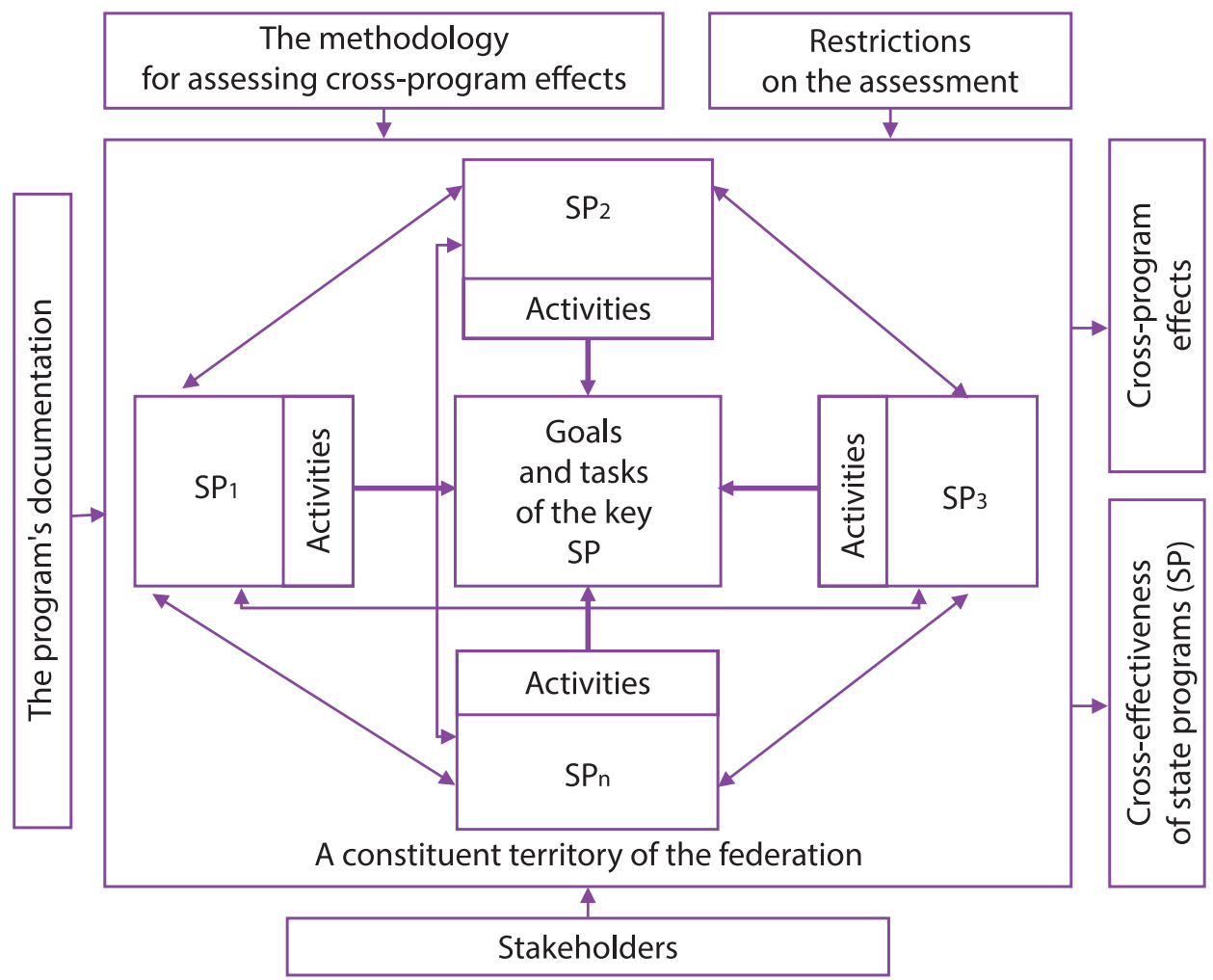

A conceptual sheme for assessing cross-program effects of a constituent territory of the federation Концептуальная схема оценки кросс-программных эффектов субъекта Федерации 
number of positive cross-program relationships that are present between the activities of a particular program and purposes/tasks of other government programs.

It is worth noting that the given diagram implies crossprogram effects to be evaluated within the predesignated key sphere. Therefore, the assessment involves only government programs whose activities in one way or another influence the state of the chosen sphere represented by the key state program of the region. If cross-program effects are assessed without delimiting the key research sphere, all government programs implemented in the constituent territory of the federation should be checked for cross-program relationships.

We suppose that the development of a mechanism and a method for assessing cross-program effects in government programs' implementation is a promising framework for further research in the field of cross-program effects. The aforementioned stakeholders are the participants of the assessment responsible for its performance. To make sure that the research results are accurate and objective, it is necessary to indicate possible barriers and limitations on the assessment of cross-program effects of the implementation of government programs: firstly, identification of cross-program links for each state program is a very labor-intensive process; secondly, the expert method of evaluation is subjective; thirdly, the analysis is focused on the examination of the links between state programs' activities, purposes and tasks solely. Nevertheless, we believe that these limitations have no reasonable grounds for refusing to assess cross-program effects, since ultimately the obtained results help enhance the efficiency of budget funds, which is the most important task for most regions of the Russian Federation under modern conditions.

The annual assessment of the government programs' effectiveness held by public authorities for each program individually allows one to get only the results of the program's implementation, including its monetary aspect. At the same time, the identification of cross-program effects will make it possible, firstly, to assess the qualitative results of state programs' implementation in a more effective and precise manner, and, secondly, to calculate approximate costs incurred in the successful development of a specific sphere in a region, as well as to digitalize the cumulative effect.

\section{CONCLUSION}

The evaluation of the cross-impact of state programs is a relatively new sphere of scientific research. Its relevance is confirmed by the findings of academic studies on strategic management and program budgeting, the modern regulatory framework, as well as the outcome of the first stage of introduction of a novel public management tool, i.e. state programs.

Cross-program effects are inevitably formed by the interaction of the set of state programs implemented in the constituent territory of the federation. However, the issue of their identification and evaluation is poorly examined in both the scientific literature and the practice of evaluating the effectiveness of government programs, although the positive shifts in this direction are obvious.

In the current research, the authors have proposed the concept and types of cross-program effects, the methodological guidelines and the conceptual diagram for their assessment. We have also characterized such indices as the cross-impact of a state program and the cross-influence of a state program, which should be taken into account when developing and adjusting state programs seeking to improve them. Nonetheless, as with any other assessment held in the economic sphere, the assessment of cross-program effects implies the development of an appropriate method that calculates the proposed quantitative indicators, which is the main avenue for further academic research.

The given methodological guidelines for the assessment of cross-program effects can be expanded by designing and justifying the methodological framework for the evaluation of cross-program effects, as well as though suggesting the ways to decrease the evaluation's labor-intensity and providing recommendations on the application of the assessment's results.

Breusova A.G. (2015). Otsenka effektivnosti gosudarstvennykh programm [Evaluation of the effectiveness of state programs]. Vestnik OmGU. Seriya: Ekonomika - Herald of Omsk University, no. 2, pp. 128-136.

Blinova E.A. (2012). Monitoring rezul'tativnosti sotsial'no-ekonomicheskogo razvitiya v Sankt-Peterburge kak raznovidnost' otsenivaniya programm [Monitoring the socio-economic development in St. Petersburg as a type of program evaluation]. Kaspiyskiy region: politika, ekonomika, kul'tura - The Caspian Region: Politics, Economics, Culture, no. 1(30), pp. 86-93.

Bykova N.V. (2014). Sovremennyy podkhod k otsenke effektivnosti gosudarstvennoy podderzhki malogo predprinimatel'stva [Modern approach to assessing the effectiveness of state support for small businesses]. Vestnik Leningradskogo gosudarstvennogo universiteta im. A.S. Pushkina - Vestnik of Pushkin Leningrad State University, no. 4, pp. 107-115.

Doroshenko S.V., Trushkova E.A., Khudyakova T.S. (2018). Predposylki i faktory otsenki kross-effektov gosudarstvennykh programm $v$ kontekste zelenoy ekonomiki [Preconditions and factors for evaluation of state cross-effects programs in the context of green economy]. Zhurnal ekonomicheskoy teorii - Russian Journal of Economic Theory, vol. 15, no. 3, pp. 420-428.

Goloushkin S.A. (2012). Problemy otsenki gosudarstvennykh programm razvitiya malogo predprinimatel'stva v sovremennoy Rossii [Evaluation problems of state programs for small business development in modern Russia]. Istoricheskaya i sotsial'noobrazovatel'naya mysl' - Historical and Social-Educational Ideas, no. 4(14), pp. 130-132.

Konovalova O.S., Akimova O.E. (2016). Gospodderzhka predprinimatel'stva kak osnova formirovaniya motivatsionnoy sredy razvitiya predprinimatel'skoy deyatel'nosti v Rossii [State support of entrepreneurship as the basis of formation of the moti- 
vational environment development of business in Russia]. Izvestiya Volgogradskogo gosudarstvennogo tekhnicheskogo universiteta - Bulletin of Volgograd State Technical University, no. 7(186), pp. 18-23.

Levitskaya N.V., Savel'ev I.I. (2016). Analiz metodik otsenki effektivnosti realizatsii gosudarstvennykh programm otdel'nykh sub'ektov Rossiyskoy Federatsii [Analysis of methods for assessing the effectiveness of the implementation of state programs of individual constituent entities of the Russian Federation]. Nauka - Science, no. 4(97), pp. 72-75.

Neupokoev N.Yu. (2014). Ob otsenke effektivnosti ispol'zovaniya byudzhetnykh sredstv (na primere podderzhki malogo i srednego biznesa) [On the evaluation of the effectiveness of using budgetary funds (the case of support for small and medium-sized businesses)]. Vestnik Altayskoy nauki - Altai Science Bulletin, no. 2,3, pp. 262-265.

Patrakhina T.N. (2015). Podkhody k otsenke effektivnosti gosudarstvennykh tselevykh programm [Approaches to evaluating the effectiveness of state target-oriented programs]. Problemy ekonomiki i menedzhmenta - Problems of Economics and Management, no. 2(42), pp. 65-68.

Rukina S.N., Samodurova V.N. (2017). Metodologicheskie podkhody k otsenke effektivnosti byudzhetnykh raskhodov, napravlennykh na realizatsiyu gosudarstvennykh programm [Methodological approaches to assessing the effectiveness of budget expenditures aimed at the implementation of state programs]. Uchet i statistika - Accounting and Statistics, no. 1(45), pp.109119.

Khudyakova T.S. (2018). [Cross-program effects: relevance of the identification and approach to the assessment]. In: Teoriya i praktika ekonomiki i predprinimatel'stva: Trudy Yubileynoy XV Mezhdunar. nauch.-prakt. konf. [Theory and practice of economics and entrepreneurship. Proc. of the $15^{\text {th }}$ Anniversary Int. sci.-pract. conf.]. Pp. 226-227.

Shash N.N. (2015). Upravlenie effektivnost'yu gosudarstvennykh programm: metodologicheskie osnovy razrabotki programmnogo byudzheta [Management of the state-funded programs' efficiency: methodological bases of development of a program-based budget]. Upravlenets - The Manager, no. 1(53), pp. 4-15.

Shmigol' N.S. (2017). Povyshenie effektivnosti programmnogo byudzhetirovaniya s uchetom luchshikh zarubezhnykh praktik [Improving the efficiency of program budgeting with the best international practices]. Ekonomika. Nalogi. Pravo - Economics. Taxes. Law, no. 5, pp. 114-125.

Ka Wai Lai I. (2015). The cross-impact of network externalities on relationship quality in exhibition sector. International Journal of Hospitality Management, no. 48, pp. 52-67.

Menck N., Weidig C., Aurich J.C. (2014). Approach for predicting production scenarios focused on cross impact analysis. Variety Management in Manufacturing. Proceedings of the 47th CIRP Conference on Manufacturing Systems. Pp. 493-498.

Weimer-Jehle W. (2006). Cross-impact balances: A system-theoretical approach to cross-impact analysis. Technological Forecasting and Social Change, no. 73, pp. 334-361.

\title{
Information about the authors
}

Tatyana S. KHUDYAKOVA

Sr. Lecturer of Quality Management Dept. Ural State University of Economics (62/45 8 Marta/Narodnoy Voli St., Ekaterinburg, 620144 , Russia). E-mail: khudyakova_t@mail.ru.

\section{Svetlana V. DOROSHENKO}

Dr. Sc. (Econ.), Associate Professor, Head of Regional Entrepreneurial Policy Dept. Institute of Economics (Ural Branch of the RAS) (29 Moskovskaya St., Ekaterinburg, 620014, Russia). E-mail: doroshenkos@mail.ru.

DOI: $10.29141 / 2218-5003-2019-10-2-5$

\section{Методологические положения оценки кросс-программных эффектов реализации государственных программ}

\author{
Т.С. Худякова, С.В. Аорошенко
}

Аннотация. Статья посвящена вопросам оценки кросс-программных эффектов реализации государственных программ. Методология исследования базируется на теории эффективности государственного управления, концепции "New Public Management" (нового государственного менеджмента) и системном подходе к его анализу. В процессе исследования применялись нормативно-правовой, компаративный, контекстный методы и вербальное моделирование. Исследование проведено на основе обзора научных работ, справочно-информационных документов и контент-анализа нормативно-правовой базы в рассматриваемой предметной области. Обоснована актуальность изучения кросс-программных эффектов, раскрыты предпосылки к совершенствованию оценки эффективности государственных программ. Уточнено понятие «кросс-программный эффект» и его отличие от мультипликативного эффекта. Представлена классификация кросс-программныхэффектов. Разработаны методологические положения и концептуальная схема оценки кросс-программных эффектов реализации государственных программ субъекта Федерации. Авторами предложены показатели “коэффициент кросс-влияния государственной программы” 
и «кросс-программная эффективность государственной программы». Обозначены трудности и ограничения представленного подхода к оценке кросс-программных эффектов. По мнению авторов, результаты этой оценки будут способствовать оптимизации и совершенствованию механизмов программного бюджетирования и стратегического планирования.

Ключевые слова: кросс-программный эффект; государственная программа; оценка кросс-программных эффектов; субъект Федерации.

JEL Classification: H83, D78, G38

Финансирование. Статья подготовлена при финансовой поддержке проекта фундаментальных исследований Уральского отделения Российской академии наук № 18-6-7-18 «Научно-технологическое развитие регионов на принципах зеленой экономики».

Аата поступления статьи: 16 декабря 2018 г.

Ссылка для цитирования: Худякова Т.С., Дорошенко С.В. Методологические положения оценки кросс-программных эффектов реализации государственных программ // Управленец. 2019. Т. 10. №2. С. 41-48. DOI: 10.29141/2218-5003-2019-10-2-5.

\section{Источники}

Бреусова А.Г. (2015). Оценка эффективности государственных программ // Вестник ОмГУ. Сер.: Экономика. № 2. С. 128-136.

Блинова Е.А. (2012). Мониторинг результативности социально-экономического развития в Санкт-Петербурге как разновидность оценивания программ // Каспийский регион: политика, экономика, культура. № 1(30). С. 86-93.

Быкова Н.В. (2014). Современный подход к оценке эффективности государственной поддержки малого предпринимательства // Вестник Ленинградского государственного университета им. А.С. Пушкина. № 4. С. 107-115.

Дорошенко С.В., Трушкова Е.А., Худякова Т.С. 2(018). Предпосылки и факторы оценки кросс-эффектов государственных программ в контексте зеленой экономики // Журнал экономической теории. Т. 15. № 3. С. 420-428.

Голоушкин С.А. (2012). Проблемы оценки государственных программ развития малого предпринимательства в современной России // Историческая и социально-образовательная мысль. № 4(14). С. 130-132.

Коновалова О.С., Акимова О.Е. (2016). Господдержка предпринимательства как основа формирования мотивационной среды развития предпринимательской деятельности в России // Известия Волгоградского государственного технического университета. № 7(186). С. 18-23.

Левицкая Н.В., Савельев И.И. (2016). Анализ методик оценки эффективности реализации государственных программ отдельных субъектов Российской Федерации // Наука. № 4(97). С. 72-75.

Неупокоев Н.Ю. (2014). Об оценке эффективности использования бюджетных средств (на примере поддержки малого и среднего бизнеса) // Вестник Алтайской науки. № 2, 3. С. 262-265.

Патрахина Т.Н. (2015). Подходы к оценке эффективности государственных целевых программ // Проблемы экономики и менеджмента. № 2(42). С 65-68.

Рукина С.Н., Самодурова В.Н. (2017). Методологические подходы к оценке эффективности бюджетных расходов, направленных на реализацию государственных программ // Учет и статистика. № 1(45). С. 109-119.

Худякова Т.С. (2018). Кросс-программные эффекты: актуальность выявления и подход к оценке // Теория и практика экономики и предпринимательства: тр. Юбил. XV Междунар. науч.-практ. конференции. С. 226-227.

Шаш Н.Н. (2015). Управление эффективностью государственных программ: методологические основы разработки программного бюджета // Управленец. № 1(53). С. 4-15.

Шмиголь Н.С. (2017). Повышение эффективности программного бюджетирования с учетом лучших зарубежных практик // Экономика. Налоги. Право. № 5. С. 114-125.

Ka Wai Lai I. (2015). The cross-impact of network externalities on relationship quality in exhibition sector. International Journal of Hospitality Management, no. 48, pp. 52-67.

Menck N., Weidig C., Aurich J.C. (2014). Approach for predicting production scenarios focused on cross impact analysis. Variety Management in Manufacturing. Proceedings of the 47th CIRP Conference on Manufacturing Systems, pp. 493-498.

Weimer-Jehle W. (2006). Cross-impact balances: A system-theoretical approach to cross-impact analysis. Technological Forecasting and Social Change, no. 73, pp. 334-361.

\section{Информация об авторах}

\section{ХУАЯКОВА Татьяна Станиславовна}

Старший преподаватель кафедры управления качеством. Уральский государственный экономический университет (620144, РФ, г. Екатеринбург, ул. 8 Марта/Народной Воли, 62/45). E-mail: khudyakova_t@mail.ru.

\section{АОРОШЕНКО Светлана Викторовна}

Аоктор экономических наук, Аоцент, завеАующий сектором региональной преАпринимательской политики. Институт экономики УрО РАН (620014, РФ, г. Екатеринбург, ул. Московская, 29). E-mail: doroshenkos@mail.ru. 